\title{
The Internet as an alternative path to internationalization?
}

\author{
Noemi Sinkovics・Rudolf R. Sinkovics • Ruey-Jer 'Bryan' Jean
}

\section{This is a pre-print (non-publisher's document). Please cite the published article:}

Sinkovics, Noemi, Rudolf R. Sinkovics, and Ruey-Jer "Bryan” Jean (2013), "The internet as an alternative path to internationalization?," International Marketing Review, 30 (2), 130155. (DOI: 10.1108/02651331311314556).

\section{Abstract}

- Purpose - While the Internet enjoys increasing interest regarding its potential to extend the global reach of firms, especially small and medium-sized firms (SMEs), little work has been done on the viability of the Internet as a new and effective path to internationalization. Specifically, it is unclear how the Internet can successfully support export marketing. This study examines the drivers and performance outcomes of two patterns of Internet use supporting export marketing: the Internet as an alternative to a physical presence and the Internet as a sales channel.

- Design/methodology/approach - Data were collected from 115 UK-based SMEs involved in "active online internationalization". Relationships are examined in a "softmodeling" partial least squares (PLS) analysis.

- Findings - The findings suggest that online channel support positively enhances export performance for SMEs. Yet, the use of the Internet as an alternative to a physical market presence does not lead to higher export performance. Specifically, born-global firms that are relying too much on the Internet are prone to fall into the "virtuality trap". Entrepreneurial firms that use the Internet as a sales channel can improve their overall performance, however.

- Research implications - This paper provides some empirical evidence of the existence of the notion of the "virtuality trap". The paper also shows that the Internet can serve a valuable complementary role. Traditional exporters are likely to use the Internet as a complement to, and thus to support, existing physical operations.

- Practical implication - Managers should focus on relationship building and on-site learning, instead of putting too much emphasis on the Internet as a substitute for a physical market presence.

- Originality/value - We develop a framework and explore previously untested relationships that suggest the Internet may play a complementary role in firm internationalization. 


\section{Key Words}

born-global; SME; ICT; internationalization; performance; virtuality trap; psychic distance

\section{Authors}

\section{Noemi Sinkovics}

Lecturer in International Business

Centre for Comparative \& International Business Research (CIBER)

The University of Manchester, Manchester Business School

Booth Street West, Manchester M15 6PB, UK.

(e-mail: noemi.sinkovics@gmail.com)

Rudolf R. Sinkovics ( $\square$ )

Professor of International Business

Centre for Comparative \& International Business Research (CIBER)

The University of Manchester, Manchester Business School

Booth Street West, Manchester M15 6PB, UK.

(e-mail: Rudolf.Sinkovics@manchester.ac.uk, Web:

http://www.personal.mbs.ac.uk/rsinkovics )

Ruey-Jer 'Bryan' Jean

Associate Professor of International Business

National Chengchi University

64, Sec.2 Zhi-Nan Road, Taipei, 11605, Taiwan

(e-mail: bryan@nccu.edu.tw)

\section{Acknowledgements}

Previous versions of this manuscript were presented at academic conferences, including AIBUKI 2011 in Liverpool, UK. We gratefully acknowledge insightful comments received from the guest editorial team of this special issue. Comments received from Olli Kuivalainen were particularly helpful in finding a strategic direction between diverging reviewers requests and contributed greatly to the development of this paper. We also are grateful for comments received from seminar participants at the Department of International Business, National Taiwan University, Taipei and the Comparative and International Business Research Centre (CIBER) seminars at The University of Manchester, Manchester Business School (http://www.mbs.ac.uk/ciber). 


\section{The Internet as an alternative path to internationalization?}

\section{STRUCTURED ABSTRACT:}

Purpose - While the Internet enjoys increasing interest regarding its potential to extend the global reach of firms, especially small and medium-sized firms (SMEs), little work has been done on the viability of the Internet as a new and effective path to internationalization. Specifically, it is unclear how the Internet can successfully support export marketing. This study examines the drivers and performance outcomes of two patterns of Internet use supporting export marketing: the Internet as an alternative to a physical presence and the Internet as a sales channel.

Design/methodology/approach - Data were collected from 115 UK-based SMEs involved in "active online internationalization". Relationships are examined in a "soft-modeling" partial least squares (PLS) analysis.

Findings - The findings suggest that online channel support positively enhances export performance for SMEs. Yet, the use of the Internet as an alternative to a physical market presence does not lead to higher export performance. Specifically, born-global firms that are relying too much on the Internet are prone to fall into the "virtuality trap". Entrepreneurial firms that use the Internet as a sales channel can improve their overall performance, however.

Research implications - This paper provides some empirical evidence of the existence of the notion of the "virtuality trap". The paper also shows that the Internet can serve a valuable complementary role. Traditional exporters are likely to use the Internet as a complement to, and thus to support, existing physical operations.

Practical implication - Managers should focus on relationship building and on-site learning, instead of putting too much emphasis on the Internet as a substitute for a physical market presence. Originality/value - We develop a framework and examine previously untested relationships that suggest the Internet may play a complementary role in firm internationalization.

KEYWORDS: born-global; SME; ICT; internationalization; performance; virtuality trap; psychic distance 


\section{Introduction}

Two major trends have offered a tremendous shift in export marketing research: the advancement of the Internet and the rapid internationalization of firms. The Internet has led to entirely new ways for exporters to access markets and improve their efficiency in terms of receiving customer orders and handling inquiries on a global basis, particularly in the case of small and medium-sized companies (SMEs) due to their limited resources (Bennett, 1997; Hamill, 1997). It has been argued that the Internet has made early internationalization a more viable and costeffective option (Sinkovics and Penz, 2005).

In line with these key trends, researchers have looked into the impact of the Internet on firm internationalization. For example, Morgan-Thomas and Bridgewater (2004) investigated the Internet as a virtual channel for export marketing. Yamin and Sinkovics (2006) studied the effect of online internationalization on psychic distance reduction. While some progress has been made, there is still little theoretical and empirical work on the viability of the Internet as a new and effective channel for reaching export markets. Many questions about the role of the Internet as a sales channel (i.e. complementary to a physical presence) or as an alternative to physical presence remain unanswered. Also, the relationship between these online alternatives and firms' export performance needs more investigation. Although Morgan-Thomas and Bridgewater (2004) examine the Internet as a virtual marketing channel, their study does not find a significant impact on export success. This is an important gap because internationalizing firms may have different paths in terms of using the Internet as an export marketing channel. Some companies are more active and rely on the Internet as a direct channel. At the same time, they may abandon most of their traditional intermediaries such as foreign distributors or agents (Gabrielsson and Gabrielsson, 2011). Other firms are more passive and use the Internet only to support their existing export activities such as advertising and promotions. However, these different patterns of firms' use of the Internet as an export marketing and internationalization channel have not been fully explored in prior literature.

Accordingly, in order to understand the use/effectiveness of the Internet as a path to firm internationalization, this paper uses empirical data to deliver a foundation for theorizing about the impact of different patterns of firms' Internet use. More specifically, this study examines ${ }^{1}$ the impact of the Internet, as an alternative to a physical market presence and as a supporting sales

The nature of this study is exploratory and aimed at theorizing rather than theory testing. It is positioned in an intermediate state between exploratory case-based research (e.g. Yamin and Sinkovics, 2006) and what Weick (1995) calls an "interim struggle" of theorizing that consists of activities such as abstracting, generalizing, selecting, synthesizing etc. to arrive at more solid opportunities for generalizations. However, as we consider explicit hypothesis testing this exploratory position can be seen as somewhat controversial. We deliberately use the "soft-modeling" capabilities of PLS-SEM (Ringle, Wende, and Will, 2005; Wold, 1980) and follow the recommendations of one reviewer to use the term "examine" for what is essentially a quasi-exploratory approach. 
channel, on export performance. In addition, we identify possible antecedents from the literature that may drive firms' decisions to rely exclusively on the Internet in foreign countries. Despite the tremendous potential of the Internet for firm internationalization, we expect that the burst of the dot.com bubble made business owners and managers more cautious. Consequently, Internet use as an alternative to a physical market presence is regarded in this paper as a decision that entails more elaborate strategic considerations than does its use as a complement to other channels. Strategic considerations are generally rooted in decision makers' perceptions of the external environment and thus our conceptual model captures factors that drive these two strategic decisions. Arguably, the conceptual framework can be labeled "messy". However, we draw on Weick (1995) to suggest that the road to theory building is not clean and straightforward.

We aspire to make several contributions. First, this study wishes to further the theorizing about the impact of different patterns of Internet use on SMEs' export performance. There is still little work focusing on this issue. Second, this study contributes to Yamin and Sinkovics' (2006) notion of the "virtuality trap", which argues that firms with stronger commitment to online internationalization may fall into the trap of generalizing their scant learning about foreign markets and customers from their online interactions, while actually not fully appreciating the complexities and thus retaining a physical and relational distance from the host markets. This, so the argument goes, may lead to a firm's poor performance in foreign markets. Third, this study also compares born globals and non-born globals (more traditional exporters) and their online internationalization paths. Overall, this study contributes to the emerging area comparing firms' paths of internationalization behaviors (Kuivalainen, Sundqvist, and Servais, 2007).

The paper proceeds as follows: In the next section, a conceptual framework provides the rationale for the drivers and performance outcomes of different paths of online internationalization, including using the Internet as a sales channel and as an alternative to a physical presence. We then propose several hypotheses suggesting relationships among the key constructs in the conceptual framework. We then assess these hypotheses in an exploratory, survey-based study. Finally, we report on the empirical findings, providing an overview and substantive discussion.

\section{Conceptual framework and hypotheses}

The term "online channel" generally refers to firms' use of the Internet as a means of connecting with the market. This use may be limited to catalogs, at one extreme, and go as far as full-blown transactional and distribution capabilities, at the other. In the context of online internationalization, a firm may actively use an online channel as a path for internationalization. However, some passive firms may only use online channels to support their existing international 
activities such as promotion and advertising. Here, we focus on two more active forms of integrating online channels into firms' internationalization strategies.

As shown in Figure 1, we propose a conceptual framework, which delineates the interrelationships between the key constructs in this research. We build the research model by integrating the resource-based view (RBV) and transaction cost theory (TCE). Applying the logic of TCE to the online context (Williamson, 1975), the Internet as an alternative to a physical presence refers to the extent to which firms use electronic integration to replace functions previously conducted by foreign distributors or agents with information acquired online, and without establishing a physical subsidiary or joint venture. Electronic integration can serve as an effective interorganizational governance mechanism without ownership (Wang, Tai, and Wei, 2006). TCE argues that environmental uncertainties are key drivers of firms' use of vertical integration (Williamson, 1975). Hence, drawing on TCE and following the electronic integration literature, we postulate that market responsiveness and environmental turbulence are two environmental uncertainty constructs that drive firms to use the Internet as an alternative to a physical presence so as to minimize transactional hazards. Furthermore, drawing on TCE and on the efficiency motive perspective of information technology (IT) adoption (Kuivalainen, Saarenketo, and Puumalainen, 2012), we suggest that the Internet's potential to reduce export barriers and enhance customer acquisition are two important drivers of Internet use as an alternative to a physical presence. In addition, according to the RBV, firms possess capabilities that are valuable, rare, inimitable and non-substitutable, which enable them to achieve a competitive advantage. Information systems (IS) research has started to apply the RBV to examine how IT resources - either alone or in conjunction with non-IT resources - impact on firm performance (e.g. Wu et al., 2006). We specifically focus on two key IT resources: the Internet as an alternative to a physical presence and the Internet as a sales channel. The Internet as an alternative to a physical presence, a form of electronic integration, can be treated as a key IT resource that leads to better performance. Furthermore, the Internet as a sales channel is an IT resource stock, which is related to how advanced a firm's IT is in supporting its export marketing. The RBV argues that organizational culture leads to higher capabilities. Thus, entrepreneurial orientation is a key organizational culture that leads firms to develop better IT resources in export marketing, by using the Internet as a sales channel.

We discuss the arguments that support the interrelationships between the key constructs in the model in the following section.

Insert Figure 1 about here 


\subsection{Psychic Distance}

Psychic distance refers to the perception of how similar or different the conditions in the new host market are to those in existing markets. Psychic distance is a construct that is relevant prior to market entry as it inhibits information flow and impedes a thorough understanding of conditions in new markets (Johanson and Vahlne, 1992; O' Grady and Lane, 1996). Specifically, psychic distance captures the extent to which a firm perceives that prior experience is a good predictor of what it expects in the new markets (Yamin and Sinkovics, 2006). A fairly recent study tries to conceptualize and operationalize psychic distance as a multiple dimension, including business and cultural distance (Evans and Mavondo, 2002). Psychic distance has been identified as a key factor in firms' foreign market entry strategies (e.g. Evans, Mavondo, and Bridson, 2008). For example, prior work has examined the impact of psychic distance on entry mode choice and firms' export performance. The literature argues that firms may choose low-control models, such as exporting, when they enter high psychic distance foreign markets, in order to minimize risks. The Internet has the potential to provide a virtual presence in the foreign market and also to provide information-processing capabilities so as to gain foreign market knowledge (Bennett, 1997). Thus, we argue that firms may perceive the use of the Internet as reducing export barriers when they enter dissimilar markets, hoping in this way to avoid risks, such as the liabilities of foreignness. Hence, we propose

HIa: If the perceived psychic distance of a country is low, there is a negative relationship between the perceived dissimilarity of business practices to those in the home country and the use of the Internet to reduce export barriers.

H1b: If the perceived psychic distance of a country is high, there is a positive relationship between the perceived similarity of business practices to those in the home country and the use of the Internet to reduce export barriers.

HIc: If the perceived psychic distance of a country is low, there is a negative relationship between the perceived dissimilarity of its national culture to that of the home country and the use of the Internet to reduce export barriers.

HId: If the perceived psychic distance of a country is high, there is a positive relationship between the perceived similarity of its national culture to that of the home country and the use of the Internet to reduce export barriers.

\subsection{Antecedents of engaging in online internationalization as an alternative to a physical presence}

Relying on the existing literature, we identified several constructs that can be argued to be antecedents of firms' use of the Internet as an alternative to a physical presence. We include the perceptions that the Internet can help to reduce export barriers, market responsiveness, market turbulence and the perception that the Internet is a useful tool for reaching foreign customers. The 
hypotheses and supporting arguments are as follows:

\subsubsection{Export barrier reduction}

Firms may face various export barriers when they conduct business abroad. Extant literature has identified different types of export barriers, such as psychic distance, competition and a lack of international experience (Leonidou, 1995). It has been argued that export barriers may be lessened by the use of the Internet and that the IT revolution has facilitated internationalization, particularly for SMEs (Bell and Loane, 2010). The combined perspectives of the efficiency motivation for IT adoption (Grewal, Comer, and Mehta, 2001) and TCE (Williamson, 1975) imply that firms will be prompted to use the Internet as an alternative to a physical presence because they seek to increase their efficiency in reducing export barriers. Mathews, Healy and Wickramasekera (2011) highlight a positive mediating impact of the Internet on the influence information availability and usage have on firms' international growth. This suggests that certain pre-market-entry concepts, such as psychic distance, may not be as relevant for the Internet user as for others, because the Internet-enabled firm communicates with the entire world regardless of economic, cultural and commercial differences. Using UK exporters, Bennett (1997) finds that firms using the Internet for exporting use fewer foreign agents or other representatives. Drawing on OECD data, Bojnec and Ferto (2009) find that the Internet stimulates manufacturing exports, while Morgan-Thomas et al. (2004) highlight that the Internet creates the possibility for exporters to serve international markets using virtual export channels. Furthermore, since, in the case of small firms, the lack of investment capital is seen as one of the largest barriers to international expansion through foreign direct investment (Leonidou, 2000), the Internet can be seen as an alternative mode of serving distant markets, whereby virtual means help to reduce physical and psychological barriers, bringing the firm closer to the customer. This leads to the following hypothesis:

\section{H2: There is a positive relationship between the perception that the Internet can help to reduce export barriers and the use of the Internet as an alternative to a physical presence.}

\subsubsection{Market responsiveness}

Market responsiveness refers to a firm's capability and inclination to respond to customer needs (Garrett, Covin, and Slevin, 2009). A responsive company is willing and able to adapt quickly to changing environmental conditions. The Internet offers speed advantages and enables firms to enhance their flexibility in responding to customer needs (Prasad, Ramamurthy, and Naidu, 2001) and developing competitive advantage (Bhatt et al., 2010). Compared to traditional local agents or distributors, online distribution channels can provide foreign customers with more timely and responsive services. The market orientation literature highlights the importance of responsiveness in 
developing successful customer relationships (Day, 1994; Helfert, Ritter, and Walter, 2002). It is also suggested that information and communication technology (ICT) is linked to a firm's ability to understand and fulfill customer needs (Nakata and Zhu, 2006). Therefore, a market-responsive company is more likely to employ the Internet as an alternative to a physical presence so as to develop its adaptive capabilities. These capabilities in turn will enhance its customer relationship management. Following prior studies that also relate the Internet to market orientation (Borges, Hoppen, and Luce, 2009), we thus hypothesize

\section{H3: There is a positive relationship between a company's market responsiveness and its use of the Internet as an alternative to a physical presence.}

\subsubsection{Environmental turbulence}

Environmental turbulence refers to the extent to which there are changes in the composition of customers and their preferences (Slater and Narver, 1994). Also referred to as market turbulence, it implies rapidly-changing buyer preferences, wide-ranging needs and wants, ongoing buyer entry and exit from the marketplace and a constant emphasis on offering new products. In a turbulent market, firms need to deal with uncertainties more proactively and effectively (Hult, Hurley, and Knight, 2004), and managers recognize that turbulent environments heighten the need to make risky investments, and sometimes, risky decisions (Calantone, Garcia, and Dröge, 2003). Therefore, firms may use the Internet as an alternative path to internationalization, and the development of a distribution system, and thus participate in electronically-mediated product and service exchange with foreign markets to safeguard and reduce uncertainties and risks (Pezderka and Sinkovics, 2011). TCE (Williamson, 1975) also suggests that firms may use an integrated channel structure when facing high market turbulence (Wang, Tai, and Wei, 2006). Following this logic, we argue that market turbulence drives firms to use the Internet as an alternative path to a physical presence. Consequently,

\section{H4: There is a positive relationship between market turbulence and Internet use as an alternative to a physical presence.}

\subsubsection{Customer reach}

Customer reach refers to the perception that the Internet can serve as a strategic tool to reach and generate more foreign customers (Bennett, 1997). Customer-oriented firms keep gathering and generating information about their foreign customers' preferences and needs. The Internet has been argued to enhance firms' market orientation through aspects such as information generation, dissemination and responsiveness (Borges, Hoppen, and Luce, 2009; Nakata and Zhu, 2006). Bell and Loane (2010) argue that the Internet provides new tools that enable a "new wave" of firms to internationalize more rapidly and engage more effectively with customers in a wider range of more 
complex business activities. The perspective of the efficiency motivation for IT adoption suggests that firms are motivated to adopt innovative IT so as to serve their customers effectively and efficiently (Grewal, Comer, and Mehta, 2001). Thus, a firm with a strong perception that the Internet is a suitable channel to reach customers will be more likely to use the Internet as an alternative to a physical presence.

H5: $\quad$ There is a positive relationship between the perception that the Internet is a useful tool for reaching foreign customers and its use as an alternative to a physical market presence.

\subsubsection{Link to performance}

In terms of the relationship between online internationalization and its effect on firm export performance, we expect both the Internet as an alternative to a physical presence and the Internet when seen purely as an online sales channel to be positively related to export performance. The logic is as follows: First, the RBV argues that IT resources and capabilities can contribute to firm value creation if IT resources are employed to leverage certain business processes and capabilities, such as enhancing supply chain capabilities (Jean, Sinkovics, and Cavusgil, 2010; Wu et al., 2006). The Internet as a virtual marketing channel and fast-track to internationalization (Sinkovics and Penz, 2005) arguably helps in side-stepping the arduous processes involved in establishing a physical market presence and delivers immediate virtual transaction capability via online shops and storefronts. Second, prior studies show that online channel commitment can enhance firm performance. For example, Hulland et al. (2007) find that the greater the firm's commitment to online channels, the higher is its online channel performance. In addition, Morgan-Thomas and Bridgewater (2004) establish that greater financial investment in Internet development and implementation results in superior firm performance in an exporting context, and Xia and Zhang (2010) find that online channels positively drive firm performance in the retailing context. While compelling arguments can be made that Internet-focused customer interaction may lead to "superstitious learning" (Levitt and March, 1988; Yamin and Sinkovics, 2006) and consequentially an ignorant or impatient internationalization pattern (Forsgren and Hagström, 2007), the dominant view in the literature offers a positive relationship between online internationalization and firm outcomes. To this end we argue

H6: There is a positive relationship between Internet use as an alternative to a physical presence and export performance.

H7: There is a positive relationship between Internet use as a sales channel and export performance. 


\subsubsection{Role of entrepreneurial orientation}

Empirical examinations of SMEs and successful internationalization processes are inextricably related to entrepreneurial firms and discussions of entrepreneurial orientation. The argument hinges on the observation that entrepreneurs are more likely to use the Internet to develop export market opportunities, and to have better export performance than less entrepreneurial firms (Loane, McNaughton, and Bell, 2004; Mostafa, Wheeler, and Jones, 2005). Hereby, entrepreneurial orientation refers to the extent to which a firm is proactive, risk taking and innovative (Matsuno, Mentzer, and Özsomer, 2002). Proactivity is related to sensing and seizing business opportunities, for example the willingness to adopt technology innovations and information and communication systems such as the Internet. To this end, the link between entrepreneurial orientation and a firm's use of the Internet in international marketing is suggested to be positive. Loane et al. (2004) argue that entrepreneurial firms use the Internet not simply as a tool to improve international performance, but, in many cases, as a core capability that underpins the firm's overall international strategy. Thus, we expect that

\section{H8: There is a positive relationship between a firm's entrepreneurial orientation and its use of the Internet as a sales channel.}

\section{Method}

\subsection{Measures}

Initially, a set of semi-structured telephone interviews were conducted with the managing directors of five UK-based firms involved in active online internationalization, to explore the topic and develop measures. The distinction between "default" and active online internationalization (AOI) was made to highlight the idea that default internationalization refers to situations where the creation of a website does not necessarily indicate an intention to "enter" a foreign market and thus internationalize (Kotha, Rindova, and Rothaermel, 2001). AOI refers to situations whereby the internationalizing firm creates websites that are intended to be vehicles for conducting online business in particular foreign countries (Yamin and Sinkovics, 2006). The websites of the selected companies (1) displayed information that indicated an attempt to actively target foreign markets, for example, pricing in various currencies, website translations, or culture-specific information, and (2) were transactional rather than purely informative in nature.

We used seven-point Likert-type multiple-item scales to operationalize the constructs and variables. Measurement scales were taken from established literature whenever possible. The interviews were used for scale development where no suitable operationalizations and measurement items could be used from prior studies (see Table 1). Given the exploratory and theory-building 
nature of this research, this was deemed appropriate. Psychic distance, as defined earlier, refers to the perception of how similar or different the conditions in the new host market are to those in existing markets. We adopted the scales of psychic distance from Evans and Mavondo (2002) and asked respondents to think about specific "close" markets and "distant" markets when responding to the psychic distance items. Internet as an export barrier reduction technique refers to the extent to which firms perceive that the Internet can help them to reduce export barriers and enhance export efficiency. The scales for this are taken from Bennet (1997). Customer reach refers to the perception that the Internet can serve as a strategic tool to reach and generate more foreign customers (Bennett, 1997). Scales are again taken from Bennet (1997) but adapted to the current context. Market turbulence refers to the extent to which there are changes in the composition of customers and their preferences (Slater and Narver, 1994). Market turbulence is measured using scales taken from Jaworski and Kohli (1993). Market responsiveness, as explained above, refers to firms' capability and inclination to respond to customer needs (Garrett, Covin, and Slevin, 2009), the scale again taken from Jaworski and Kohli (1993). Entrepreneurial orientation refers to the extent to which a firm is proactive, risk taking and innovative and is adapted from Matsuno, Mentzer and Özsomer (2002). Three items were developed to measure the use of the Internet as an alternative to a physical presence. The scale measures the extent to which the Internet fully replaces the marketing functions of agents and distributors in foreign markets. The use of the Internet as a sales channel in this study refers to conducting overall export marketing functions via the Internet. Scales are taken from Wu et al.'s (2006) study. Export performance in this study refers to the extent to which firms are satisfied with their export activities, including sales growth, sales volume etc. The export performance scale was taken from Katiskeas et al. (2000).

To control for firms' born-globalness, we draw on Sundqvist, Kuivalainen and Cadogan's (2011) definition. Born globals span large geographical distances, ideally the globe, but if not at least three continents by definition (Sundqvist, Kuivalainen, and Cadogan, 2011). In order to conceptually qualify as a born global, a firm needs to have internationalized within three years of its inception and to export at least 25 percent of its total sales. As most born globals fall into the category of SMEs, they are inherently more resource poor than large firms (Hodgkinson, 2008). Hence, as is also posited in the literature (e.g. Kotha, Rindova, and Rothaermel, 2001; Servais, Madsen, and Rasmussen, 2006), it can be expected that born globals will attempt to rely on the Internet - arguably even rely too much on the Internet - to meet the challenge of spanning these large geographical distances. We also control for Internet experience and export experience, as they are proxies for Internet and export capabilities, respectively. While the importance of export experience is well documented in the literature (Leonidou, Katsikeas, and Coudounaris, 2010), Internet experience (capabilities) needs to be controlled for, as Internet use alone does not constitute 
a capability (Wu et al., 2006). We also control for industry affiliation, as this too may affect how lucrative a firm's reliance on the Internet would be. High-technology industry affiliation is sometimes used as a proxy for innovativeness (Kirchhoff, 1991) and consequently for entrepreneurial posture (Covin and Slevin, 1991).

\section{Insert Table 1 about here}

\subsection{Sampling frame and data collection}

The target population was defined as UK-based SMEs involved in exporting activities, using a website. The European Commission's definition of SMEs was used, that is, "the category of micro, small and medium-sized enterprises (SMEs) is made up of enterprises which employ fewer than 250 persons and which have an annual turnover not exceeding EUR 50 million, and/or an annual balance sheet total not exceeding EUR 43 million"(European Commission, 2003). In the first step, the criteria were entered into the FAME (Bureau van Dijk) database. It provides detailed, financial, descriptive and ownership information on over 3.1 million public and private companies in the UK and Ireland. In order to determine whether the companies were involved in exporting, we examined whether their profit and loss accounts contained the item "overseas turnover". The database contained 8,605 companies corresponding to the abovementioned specifications. We drew a random sample of 1,000 companies. The next step involved inspecting the websites of the selected companies. Those with non-functioning sites or with no explicit exporting activities had to be replaced. As a contact person, the Marketing, Export or Sales Manager was selected; where they were not indicated in FAME, the Managing Director was selected.

\subsection{Survey response and informant evaluation}

The first round took the form of a postal mail-out of 1,000 questionnaires. This resulted in 35 completed and returned questionnaires within two weeks. In order to increase the response rate, companies were called individually. By the fifth week after the mail-out, 74 responses had been returned. To further improve the response rate, a reminder email was sent out to all managers who had agreed on the phone to complete the survey. In total, we received back 115 usable questionnaires, a response rate of 11.5 percent.

A random sample of 82 companies was drawn from amongst the non-respondents (who explicitly indicated a non-willingness to respond via post, email or phone) in order to test for nonresponse bias. The majority of non-respondents gave shortage of time as the major reason for their non-response, while a mere 6 percent indicated that they had been discouraged by the length of the 
questionnaire (the original questionnaire had 252 scale items). 27 percent stated that their company policy prohibited any participation in surveys. The remaining companies stated their lack of interest in the topic or other reasons (for example a new manager, bankruptcy of the company etc.). However, none of the refusals were due to the substance of the questionnaire. Finally, we further assessed non-response bias by comparing selected attribute means of early respondents with those of late respondents (Armstrong and Overton, 1977). The comparison of the means yielded no significant differences.

\subsection{Common method bias}

We assessed common method bias by applying two separate procedures. In a first step, Harman's one-factor test (Podsakoff and Organ, 1986) was performed using principal component analysis of all the items included in the study. Since no dominant factor emerged, we conclude that there is no evidence suggesting the presence of common method bias in the study.

We then advanced towards a more involved means of examining common method bias, correlating objective data with subjective data on the same variable. The survey included a question where respondents were asked to indicate their export ratio. We used objective information about the selected firms' export ratios extracted from the FAME database and compared it to the answers given in the questionnaires. The test yielded a significant and positive correlation coefficient of 0.675, again providing support for the assumption that there is no common method bias limiting generalizations from our findings.

\section{Assessment of the research model and hypotheses}

\subsection{Measurement model assessment}

First, we examined the loadings of the individual items with their respective constructs (see Table 1). All measurement items with loadings above 0.4 were retained (Ainuddin et al., 2007). The loadings for the measures range from 0.6552 to 0.999 , with most items exceeding the threshold level of 0.7, recommended by Fornell and Larcker (1981). In a second step, we examined Cronbach's alpha and the composite reliability values for each latent variable. Both measures suggest reasonable reliability, with all values exceeding the 0.7 threshold (Nunnally and Bernstein, 1994).

Convergent validity was assessed using average variance extracted (AVE) (see Table 4), as suggested by Fornell and Larcker (1981). Convergent validity was found to be satisfactory as all the values are greater than 0.5 (Henseler, Ringle, and Sinkovics, 2009). We further checked discriminant validity using two methods, the Fornell-Larcker criterion (1981) and the cross-loadings 
of items. For each variable, the AVE is higher than its highest squared correlation with any other variable, thus we can assume an adequate level of discriminant validity. This is supported by the cross-loadings. The loading of each indicator is greater than all of its cross-loadings (Henseler, Ringle, and Sinkovics, 2009).

\subsection{Structural model assessment}

After ensuring that the outer model was both reliable and valid, we examined the inner path model using SmartPLS (Ringle, Wende, and Will, 2005). The explanatory power of a partial least squares (PLS) model is determined by the amount of variance explained $\left(\mathrm{R}^{2}\right)$ by the endogenous latent variables (Henseler, Ringle, and Sinkovics, 2009). The $\mathrm{R}^{2}$ value for export performance is 0.4664. Chin (1998) sets thresholds of 0.67, 0.33, and 0.19 for substantial, moderate, and weak inner path models respectively. Henseler et al. (2009) state that, if an endogenous latent variable is explained by only one or two exogenous latent variables, then a "moderate" $\mathrm{R}^{2}$ value is acceptable. Although our coefficient for determination is medium, our results can be deemed as relevant and indicatory for future research as the prediction capability of the model is sufficiently high - both the redundancy and communality values being greater than 0 (cv redundancy $=0.130$; $\mathrm{cv}$ communality $=0.736$ ). To check the prediction capability of the model, we used Stone-Geisser's $Q^{2}$, as suggested in Henseler et al. (2009), applying the blindfolding method (Tenenhaus et al., 2005).

\subsection{Results and discussion}

Table 2 and Table 3 exhibit the characteristics of the respondent firms. 50.43 percent of the respondents can be categorized as born globals. These firms all internationalized within three years of their establishment and are now exporting more than 25 percent of their total sales to at least three continents (Kuivalainen, Sundqvist, and Servais, 2007). In terms of industry affiliations, 53.04 percent of the cases belong to the high-tech sector (e.g. software, engineering or computing) and 46.96 percent to the low-tech sector (e.g. food and beverages or clothing).

\section{Insert Table 2 and Table 3 about here}

The average firm age indicates that, although the born globals in our sample are still "younger" than non-born globals, with an average of 29 and 31 years in the low-tech and high-tech industries, respectively, they are past their start-up phase. In order to test whether this fact hampers any inferences being drawn from the comparison between the born globals and the non-born globals, we conducted an independent sample t-test, which indicated that the mean difference in firm age was significant. From this we conclude that, even though some of the born global firms have 
already developed into more mature organizations, we are still able to find relevant differences in terms of the impact of Internet-based capabilities on export performance, between born globals and non-born globals.

Hypotheses 1a to 1d claim that the difference in psychic distance affects the use of the Internet as a means to reduce export barriers. That is, if the perceived psychic distance of a country is high, firms' use of the Internet to reduce export barriers is suggested to be higher. The results support Hypotheses 1a and 1b. A potential explanation is that when business practices are very different in the host country, firms trust intermediaries less because they don't know what to expect. Hence they may perceive it to be safer to rely on the Internet than to engage directly with intermediaries. Hypotheses 1c is not supported. Hypothesis 1d is significant but positive. It implies that contrary to expectations, firms rely more on the Internet to reduce barriers when exporting to a psychically close country in terms of culture. The explanation for this result is probably less trustrelated than in the case of business practices. The motivation may lie in the perception that intermediaries are not necessary and too cost-intensive. Hypothesis 2, that the use of the Internet as a tool to help reduce export barriers is linked to the use of the Internet as an alternative to a physical presence, is not supported by the results $(b=0.062)$. A possible reason may be, as Yamin and Sinkovics (2006) highlight, "the danger of falling into a virtuality trap when use the Internet as [an] alternative to [a] physical presence". Another explanation may be that exporters are concerned about damaging their relationships with existing agents and distributors. As a consequence, their motivation to completely replace traditional export marketing channels with the Internet is reduced. Hypothesis 3 states that market responsiveness will result in using the Internet as an alternative to a physical market presence. Our results also support this hypothesis $(b=0.247, p<0.05)$. Hypothesis 4 is significant but contrary to expectations there is a negative relationship between market turbulence and Internet use as an alternative to a physical presence. The expectation was that the Internet may be an effective tool for customers to communicate their preferences and needs so that the firm can fulfil them promptly. However, the results suggest that when market turbulence is high firms prefer to be physically presence in the market, probably to build good customer relationships and trust.

\section{Insert Table 4 about here}

Further, Hypothesis 5 states that customer reach will result in a high level of exploiting the Internet as an alternative to a physical market presence. Our results support this hypothesis $(b=0.220, p<0.05)$. Hypotheses 6 and 7 claim that online internationalization, that is both using the Internet as an alternative to a physical market presence and using the Internet as a sales channel, will positively impact on export performance. Hypothesis 6 is not significant, but the effect on 
performance of using the Internet as a sales channel (Hypothesis 7) is significant and supported. One plausible reason for this is that the use of the Internet as an alternative to a physical presence reduces personal interactions, which traditional intermediaries would provide. This, in turn, could generate significant mistakes regarding market servicing and operational issues that have detrimental effects on the bottom line. Finally, Hypothesis 8 states that entrepreneurial orientation will positively influence the use of the Internet as a sales channel. The results provide support for this hypothesis $(\mathrm{b}=0.676, \mathrm{p}<0.05)$.

\subsection{Additional analysis}

We performed additional analyses to examine a set of variables which we considered outside the conceptual focus of the paper, but important in terms of their potential interaction with core dimensions of this study. We thus formally controlled for a set of variables that may also influence the relationship between firms' online internationalization strategies and their export performance. In terms of these interaction effects, we adopted Jaccard and Turrisi's approach (2003). In this study, born globalness was measured by an export sales ratio of more than 25 percent of total sales. Furthermore, the firms were required to have internationalized within three years of their inception to at least three continents (Kuivalainen, Sundqvist, and Servais, 2007). The results (see Table 5) are intriguing as they are contrary to intuitive expectations based on the extant literature. While the relationship between adopting the Internet as an alternative to a physical presence and export performance is only significant at the 0.10 level for the full sample, an interesting story unfolds when we look at the control groups. This weak positive relationship persists in the case of non-born globals and firms with strong Internet experience (more than ten years). Firms with strong export experience (more than 50 percent export sales) and firms with low-tech industry affiliations seem to benefit from a significantly positive relationship between having an alternative presence online and performance. At the same time, born globals seem to incur significant financial losses when they rely on the Internet as an alternative to a physical presence. While critics may blame our generous operationalization of born globals (a minimum export sales ratio of 25 percent) for this result, the fact that this relationship is insignificant for firms with an export ratio of less than 50 percent indicates that the root cause of this result is due to other factors. A closer look at the paths leading to the adoption of the Internet as an alternative to a physical presence reveals that born globals perceive the Internet as a means to reduce export barriers, while non-born globals do not. This finding suggests that born-global firms are more likely to fall into the virtuality trap and rely too much on the Internet as an alternative to a physical presence, which reduces their ability to gain insights from local customers and learn from the specific host market context. They try to leverage the Internet as a vehicle that substitutes for a physical presence, which is ultimately detrimental to 
their export performance, especially in countries where they perceive business practices to be similar to those in their home country. The findings are consistent with Yamin and Sinkovics' (2006) argument that online internationalization may drive exporters to fall into the virtuality trap and make them prone to reduced performance.

\section{Insert Table 5 and Figure 2 about here}

The companies in our sample that are classified as low-tech firms belong to industries such as clothing, consulting, construction, food/beverages, transport, furniture, etc., while the high-tech subgroup comprises firms affiliated with electronics, software, computing, telecoms, engineering, pharma/chemicals, publishing, industrial goods, healthcare etc. Both born-globals and non-born globals are more or less equally represented in the high-tech and low-tech categories (see Table 2). A possible explanation for these above results may lie in the type of customer assistance required for the products of the high-tech subgroup relative to the low-tech subgroup, which makes a physical presence more desirable. Also, the successful marketing of high-tech industry products and services may require a higher level of customer trust than is required for low-tech industry products. Non-born global firms and those with more Internet experience, in accordance with the overall results for the full sample, seem to be more cautious of relying exclusively on the Internet as an alternative to a physical presence when they regard business practices in foreign countries as being similar to those in their home country. At the same time, non-born global firms readily rely on the Internet in countries they perceive to be close from a cultural point of view. This implies that, while managers are more sensitive to nuances in the business practice differences between psychically close countries, they appear to be more insensitive to these nuances in psychically distant countries and rely on the Internet for compensation. This seems to be especially true for firms with a high degree of Internet experience.

The use of the Internet as a complement to other channels has a strong positive performance impact on the overall sample as well as for the non-born global, low-tech, and a low degree of Internet experience ( $<10$ years) categories. A possible explanation of why firms with less Internet experience should reap more benefits from Internet sales channels may be that they are compensating for this lack of experience by employing staff with more up-to-date skills and capabilities. This would also explain why firms with more Internet experience ( $>10$ years) only show a positive and significant relationship at the 0.10 level. Their staff may be more conservative and less inclined to adopt the newest techniques in website and online channel development. The use of the Internet as a sales channel seems to have a positive influence on export performance, regardless of a firm's export experience. This may imply the strengthening of consumer preferences 
regarding online shopping. At the same time, the nature of the products (low-tech versus high-tech) also seems to play a major role for the economic viability of online sales channels.

The relationship between entrepreneurial disposition and the use of the Internet as a sales channel is positive and significant for all subgroups. This indicates that the use of high-tech industries as a proxy for innovativeness, and consequently for entrepreneurship (Kirchhoff, 1991), is not adequate.

\section{Discussion and conclusion}

The advancement and widespread use of the Internet provides firms with great opportunities to leverage their information-processing capabilities and global connectivity potential. It offers to enhance business processes and improve competitive advantage, not only for domestic or large international firms, but also for SMEs, in which area the Internet has produced a whole new discussion on export marketing, rapid internationalization opportunities and virtual customer servicing. However, while studies on the importance of the Internet are mushrooming, the perspective is usually an overly positive one, and balanced perspectives on the opportunities and threats of this medium are largely missing. Drawing from the online internationalization and exporting literature, and based on the UK exporting context, this study attempts to identify different paths of online internationalization, and examine whether (a) using the Internet as an alternative to a physical presence in foreign markets and (b) using it as a sales channel result in different effects regarding export performance. These two types of online internationalization differ in terms of their use to complement or substitute for traditional agencies when entering foreign markets. In addition, this study identifies a set of antecedents for situations when the Internet is seen as an alternative to a physical presence. The results of this study have implications for theorizing and thus for future theory development.

First, in terms of the impact of online internationalization on export performance, this study finds that an online sales channel strategy positively enhances export performance for SMEs. However, the use of the Internet as an alternative to a physical market presence does not by default lead to higher export performance. This finding is consistent with the RBV, which argues that IT resources alone cannot contribute to a firm's competitive advantage (Jean, 2007; Jean, Sinkovics, and Kim, 2008). Instead, IT resources should be complemented with both IT capabilities and non-IT resources and capabilities in order to drive higher firm performance levels. In the context of exporting, SMEs need to leverage the Internet as a sales channel, by providing additional advertising and delivery support, which traditional foreign agencies normally offer. Thus organized, that is, if the Internet and online strategy is adequately complemented with an offline strategy via, 
for example, traditional intermediaries, this may drive greater export performance. When a firm only focuses on using the Internet to replace traditional agents, the exporters lose out on personal interactions and on host-market learning, facilitated through their foreign customers, which has a negative knock-on effect regarding export performance.

In all, the results show that the advancement of the Internet provides great potential for exporters to reach new markets and new customers, but firms need to be cautious when interpreting online information to create new knowledge. As Nguyen et al.'s (2006) study indicates, knowledge internalization plays a critical facilitating role for exporters wishing to integrate different sources of online information and create new knowledge. More specifically, our results show that born globals, keen to engage in exporting activities from a very early stage and thus using the Internet as an alternative to a physical presence, are more likely to rely predominantly on this medium and thus end up in a "virtuality trap" than traditional firms that internationalize later. In addition, traditional export marketing channels such as agents and distributors can avoid the threat of disintermediation by increasing their value-added services, for example by acting as filters to help exporters internalize knowledge effectively. In terms of the antecedents of online internationalization, this study does not find support for the perception that using the Internet as a tool to reduce export barriers is positively related to using it as an alternative to a physical presence. This may be because most SMEs still face high export barriers in their internationalization process and are unwilling to use the Internet as the only way to mitigate these barriers. However, conspicuously, the analysis of our control variables shows that this relationship is supported in the group of born-global firms. To this end, born globals, in many cases constrained by resources and capabilities, are more likely to treat the Internet as a major and overly-powerful tool for enhancing their export marketing capabilities. As a result, they feel that the Internet helps them to reduce their export barriers (Gregory, Karavdic, and Zou, 2007; Prasad, Ramamurthy, and Naidu, 2001).

The results of this study also show that market responsiveness and customer acquisition are positively related to the use of the Internet as an alternative to a physical presence. These findings are consistent with research that highlights the impact of the Internet on market orientation, in terms of generating customer information and responding quickly to customer needs (Borges, Hoppen, and Luce, 2009; Nakata and Zhu, 2006).

The findings also indicate that environmental turbulence is negatively related to the use of the Internet as an alternative to a physical presence in international markets. This result is consistent with TCE theory and its recent descendant, the virtual integration theory (Wang, Tai, and Wei, 2006), which suggests a lack of flexibility in online channel integration. The implication of this finding is that firms need to consider the dynamism of the environment as a crucial variable when 
making information systems and Internet integration decisions.

With regards to the role of entrepreneurial orientation, this study finds that entrepreneurially-oriented firms are more willing to adopt the Internet as a sales channel to support their export marketing. This finding is consistent with recent work by Hulland et al. (2007) and Mostafa et al. (2005) which highlights the important role of a firm's strategic orientation in determining the level of its online commitment.

The results of this study should be interpreted in light of several inherent limitations. First, this study only uses cross-sectional data, and thus does not offer a time-invariant perspective, which may be specifically relevant in this fast-paced and continuously changing technological environment. Second, this study focuses on UK exporters, which may exhibit idiosyncratic perspectives on their Internet deployment and internationalization approaches. Future studies should try to look at other contexts such as emerging markets. Many exporters in emerging markets may face resource and institutional constraints to building websites in support of export marketing, and thus rely more heavily on third party online intermediaries. Exploring the influence of online intermediaries on export marketing appears to be a promising avenue for future research. Third, this study does not directly test the different resources and capabilities of born globals and non-born globals and their effects on export performance. Future work is encouraged, comprising large samples and spanning firms with different paths of internationalization in an attempt to explore this important issue further. In addition, this study does not explicitly test the impact of existing foreign channel structures on the effectiveness of a firm's use of the Internet to support export marketing. It would be worth examining this interesting issue in the future. Furthermore, the scales used in this study have been taken from the existing literature and, although they serve the purpose of supplying insights for theorizing, more suitable scales are needed that are explicitly designed to test these concepts. Future research may wish to cater for this need and develop and test better scales for capturing the concepts of the use of the Internet as an alternative to a physical presence and its use as a sales channel. Another issue that may be addressed in future research is related to different levels of measurement. Cultural distance and business distance were captured by asking about specific "close" and "distant" markets, thus introducing another level of analysis in the study. While limited to the dimension "Internet as export barrier reduction" in our study, a small potential of biased results exists (Oliveira, Cadogan, and Souchon, 2012). Also, as mentioned at the beginning of the "Results and discussion" section, the born globals included in this sample are already in their adolescent stage. Given their age, although they seem to be among the early adopters of Internet technology, it can be expected that the examination of born globals in their infancy stage (aged three to seven years) may yield different insights. Future research may wish to compare the online 
internationalization paths of born globals in different stages of their life cycles.

Nevertheless, this study contributes to the emerging literature on different paths of online internationalization by suggesting that exporting firms with different paths (i.e. born globals and late exporters) may exhibit differences. Born-global firms seem to be more likely to adopt the Internet for exporting in a more aggressive way and to treat it as an alternative to having a physical presence in foreign markets. This incurs the risks of misreading foreign market information and is likely to be detrimental to the born globals' export performance. In contrast, traditional exporters are likely to use the Internet only to complement and support their existing export functions, which in turn leads to a synergistic approach, resource leveraging and better export performance. To this end, this study arguably identifies a promising area of inquiry in international marketing and opens up avenues for further research on online internationalization paths.

\section{References}

Ainuddin, R.A., Beamish, P.W., Hulland, J.S., and Rouse, M.J. (2007), "Resource attributes and firm performance in international joint ventures", Journal of World Business, Vol. 42 No. 1, pp. 47-60.

Armstrong, J.S. and Overton, T.S. (1977), "Estimating nonresponse bias in mail surveys", Journal of Marketing Research, Vol. 14 No. 3, pp. 396-402.

Bell, J. and Loane, S. (2010), "'New-wave' global firms: Web 2.0 and SME internationalisation", Journal of Marketing Management, Vol. 26 No. 3-4, pp. 213-29.

Bennett, R. (1997), "Export marketing and the internet: Experiences of web site use and perceptions of export barriers among UK businesses", International Marketing Review, Vol. 14 No. 5, pp. 324-44.

Bhatt, G., Emdad, A., Roberts, N., and Grover, V. (2010), "Building and leveraging information in dynamic environments: The role of IT infrastructure flexibility as enabler of organizational responsiveness and competitive advantage", Information \& Management, Vol. 47 No. 7-8, pp. 341-49.

Bojnec, S. and Fertö, I. (2009), "Impact of the internet on manufacturing trade", The Journal of Computer Information Systems, Vol. 50 No. 1, pp. 124-33.

Borges, M., Hoppen, N., and Luce, F.B. (2009), "Information technology impact on market orientation in ebusiness", Journal of Business Research, Vol. 62 No. 9, pp. 883-90.

Calantone, R., Garcia, R., and Dröge, C. (2003), "The effects of environmental turbulence on new product development strategy planning", Journal of Product Innovation Management, Vol. 20 No. 2, pp. 90103.

Chin, W.W. (1998), "The partial least squares approach to structural equation modelling", in Marcoulides, G.A. (Ed.), Modern methods for business research, Lawrence Erlbaum Associates, Mahwah, NJ, pp. 295-358.

Covin, J.G. and Slevin, D.P. (1991), "A conceptual model of entrepreneurship as firm behavior", Entrepreneurship: Theory \& Practice, Vol. 16 No. 1, pp. 7-25.

Day, G.S. (1994), "The capabilities of market-driven organizations", Journal of Marketing, Vol. 58 No. 4, pp. 37-52.

European Commission (2003, June 20), Commission recommendation of 6 may 2003 concerning the definition of micro, small and medium-sized enterprises (L 124/36), [Online], Available (2008, June 20) http://europa.eu/eur-lex/pri/en/oj/dat/2003/1_124/1_12420030520en00360041.pdf.

Evans, J. and Mavondo, F.T. (2002), "Psychic distance and organizational performance: An empirical examination of international retailing operations", Journal of International Business Studies, Vol. 33 No. 3, pp. 515-32.

Evans, J., Mavondo, F.T., and Bridson, K. (2008), "Psychic distance: Antecedents, retail strategy implications, and performance outcomes", Journal of International Marketing, Vol. 16 No. 2, pp. $32-63$. 
Fornell, C. and Larcker, D.F. (1981), "Structural equation models with unobservable variables and measurement error: Algebra and statistics", Journal of Marketing Research, Vol. 18 No. 3, pp. 38288.

Forsgren, M. and Hagström, P. (2007), "Ignorant and impatient internationalization?: The Uppsala model and internationalization patterns for internet-related firms", Critical Perspectives on International Business, Vol. 3 No. 4, pp. 291-305.

Gabrielsson, M. and Gabrielsson, P. (2011), "Internet-based sales channel strategies of born global firms", International Business Review, Vol. 20 No. 1, pp. 88-99.

Garrett, R.P., Covin, J.G., and Slevin, D.P. (2009), "Market responsiveness, top management risk taking, and the role of strategic learning as determinants of market pioneering", Journal of Business Research, Vol. 62 No. 8, pp. 782-88.

Gregory, G., Karavdic, M., and Zou, S. (2007), "The effects of e-commerce drivers on export marketing strategy", Journal of International Marketing, Vol. 15 No. 2, pp. 30-57.

Grewal, R., Comer, J.M., and Mehta, R. (2001), "An investigation into the antecedents of organizational participation in business-to-business electronic markets", Journal of Marketing, Vol. 65 No. 3, pp. $17-33$

Hamill, J. (1997), "The internet and international marketing", International Marketing Review, Vol. 14 No. 5, pp. 300-23.

Helfert, G., Ritter, T., and Walter, A. (2002), "Redefining market orientation from a relationship perspective: Theoretical considerations and empirical results", European Journal of Marketing, Vol. 36 No. 9, pp. 1119-39.

Henseler, J., Ringle, C.M., and Sinkovics, R.R. (2009), "The use of partial least squares path modeling in international marketing", in Sinkovics, R.R. and Ghauri, P.N. (Eds.), Advances in international marketing Vol. 20, Emerald JAI Press, Bingley, pp. 277-319.

Hodgkinson, A. (2008), "What drives regional export performance? Comparing the relative significance of market determined and internal resource factors", Australasian Journal of Regional Studies, Vol. 14 No. 1, pp. 27-46.

Hulland, J., Wade, M.R., and Antia, K.D. (2007), "The impact of capabilities and prior investments on online channel commitment and performance", Journal of Management Information Systems, Vol. 23 No. 4, pp. 109-42.

Hult, G.T.M., Hurley, R.F., and Knight, G.A. (2004), "Innovativeness: Its antecedents and impact on business performance", Industrial Marketing Management, Vol. 33 No. 5, pp. 429-38.

Jaccard, J. and Turrisi, R. (2003), Interaction effects in multiple regression (Quantitative applications in the social sciences), Sage Publications, Thousand Oaks, California.

Jaworski, B.J. and Kohli, A.K. (1993), "Market orientation: Antecedents and consequences", Journal of Marketing, Vol. 57 No. 3, pp. 53-70.

Jean, R.-J.B. (2007), "The ambiguous relationship of ICT and organizational performance: A literature review", Critical Perspectives on International Business, Vol. 3 No. 4, pp. 306-21.

Jean, R.-J.B., Sinkovics, R.R., and Cavusgil, S.T. (2010), "Enhancing international customer-supplier relationships through IT resources: A study of Taiwanese electronics suppliers", Journal of International Business Studies, Vol. 41 No. 7, pp. 1218-39.

Jean, R.-J.B., Sinkovics, R.R., and Kim, D. (2008), "Information technology and organizational performance within international business to business relationships: A review and an integrated conceptual framework", International Marketing Review, Vol. 25 No. 5, pp. 563-83.

Johanson, J. and Vahlne, J.-E. (1992), "Management of foreign market entry", Scandinavian International Business Review, Vol. 1 No. 3, pp. 9-27.

Katsikeas, C.S., Leonidou, C.L., and Morgan, A.N. (2000), "Firm-level export performance assessment: Review, evaluation, and development", Journal of the Academy of Marketing Science, Vol. 28 No. 4, pp. 493-511.

Kirchhoff, B.A. (1991), "Entrepreneurship's contribution to economics", Entrepreneurship: Theory \& Practice, Vol. 16 No. 2, pp. 93-112.

Kotha, S., Rindova, V.P., and Rothaermel, F.T. (2001), "Assets and actions: Firm-specific factors in the internationalization of U.S. Internet firms", Journal of International Business Studies, Vol. 32 No. 4, pp. 769-91.

Kuivalainen, O., Saarenketo, S., and Puumalainen, K. (2012), "Start-up patterns of internationalization: A framework and its application in the context of knowledge-intensive SMEs", European Management Journal, Vol. in press, (doi: 10.1016/j.emj.2012.01.001). 
Kuivalainen, O., Sundqvist, S., and Servais, P. (2007), "Firms' degree of born-globalness, international entrepreneurial orientation and export performance", Journal of World Business, Vol. 42 No. 3, pp. 253-67.

Leonidou, L.C. (1995), "Export barriers: Non-exporters' perceptions", International Marketing Review, Vol. 12 No. 1, pp. 4-25.

Leonidou, L.C. (2000), "Barriers to export management: An organizational and internationalization analysis", Journal of International Management, Vol. 6 No. 2, pp. 121-48.

Leonidou, L.C., Katsikeas, C.S., and Coudounaris, D.N. (2010), "Five decades of business research into exporting: A bibliographic analysis", Journal of International Management, Vol. 16 No. 1, pp. 78 91.

Levitt, B. and March, J.G. (1988), "Organizational learning", Annual Review of Sociology, Vol. 14, pp. 31940.

Loane, S., McNaughton, R.B., and Bell, J. (2004), "The internationalization of internet-enabled entrepreneurial firms: Evidence from Europe and North America", Canadian Journal of Administrative Sciences, Vol. 21 No. 1, pp. 79-97.

Manimala, M.J. (1999), Entrepreneurial policies and strategies - the innovator's choice, Sage Publications, Thousand Oaks, CA.

Mathews, S., Healy, M., and Wickramasekera, R. (2011), "The internetalisation of information, knowledge, and interaction components of the firm's internationalisation process", Journal of Marketing Management, pp. 1-22.

Matsuno, K., Mentzer, J.T., and Özsomer, A. (2002), "The effects of entrepreneurial proclivity and market orientation on business performance", Journal of Marketing, Vol. 66 No. 3, pp. 18-32.

Morgan-Thomas, A. and Bridgewater, S. (2004), "Internet and exporting: Determinants of success in virtual export channels", International Marketing Review, Vol. 21 No. 4, pp. 393-408.

Mostafa, R., Wheeler, C., and Jones, M. (2005), "Entrepreneurial orientation, commitment to the internet and export performance in small and medium sized exporting firms", Journal of International Entrepreneurship, Vol. 3 No. 4, pp. 291-302.

Nakata, C. and Zhu, Z. (2006), "Information technology and customer orientation: A study of direct, mediated, and interactive linkages", Journal of Marketing Management, Vol. 22 No. 3/4, pp. 319-54.

Nguyen, T.D. and Barrett, N.J. (2006), "The knowledge-creating role of the internet in international business: Evidence from Vietnam", Journal of International Marketing, Vol. 14 No. 2, pp. 116-47.

Noordewier, T.G., John, G., and Nevin, J.R. (1990), "Performance outcomes of purchasing arrangements in industrial buyer-vendor relationships", Journal of Marketing, Vol. 54 No. 4, pp. 80.

Nunnally, J.C. and Bernstein, I.H. (1994), Psychometric theory (3rd ed.), McGraw-Hill, New York.

O' Grady, S. and Lane, H.W. (1996), "The psychic distance paradox", Journal of International Business Studies, Vol. 27 No. 2, pp. 309-33.

Oliveira, J.S., Cadogan, J.W., and Souchon, A. (2012), "Level of analysis in export performance research", International Marketing Review, Vol. 29 No. 1, pp. 114-27.

Pezderka, N. and Sinkovics, R.R. (2011), "A conceptualization of e-risk perceptions and implications for small firm active online internationalization", International Business Review, Vol. 20 No. 4, pp. 40922.

Podsakoff, P.M. and Organ, D.W. (1986), "Self-reports in organizational research: Problems and prospects", Journal of Management, Vol. 12 No. 4, pp. 531-44.

Prasad, V.K., Ramamurthy, K., and Naidu, G.M. (2001), "The influence of internet-marketing integration on marketing competencies and export performance", Journal of International Marketing, Vol. 9 No. 4, pp. 82-110.

Ringle, C.M., Wende, S., and Will, A. (2005), Smartpls 2.0 m3, University of Hamburg, Hamburg, Germany.

Servais, P., Madsen, T.K., and Rasmussen, E.S. (2006), "Small manufacturing firms' involvement in international e-business activities", Advances in international marketing Vol. 17, Emerald Group Publishing Limited, Bingley, UK., pp. 297-317.

Sinkovics, R. and Penz, E. (2005), "Empowerment of SME websites: Development of a web-empowerment scale and preliminary evidence", Journal of International Entrepreneurship, Vol. 3 No. 4, pp. 30315.

Skarmeas, D., Katsikeas, C.S., and Schlegelmilch, B.B. (2002), "Drivers of commitment and its impact on performance in cross-cultural buyers-seller relationships: The importer's perspective", Journal of International Business Studies, Vol. 33 No. 4, pp. 757. 
Slater, S.F. and Narver, J.C. (1994), "Does competitive environment moderate the market orientationperformance relationship?", Journal of Marketing, Vol. 58 No. 1, pp. 46-55.

Sundqvist, S., Kuivalainen, O., and Cadogan, J.W. (2011), "Contingency factors in international entrepreneurial orientation - performance relations of firms with different levels of internationalization", in Hutson, E., Sinkovics, R.R., and Berrill, J. (Eds.), Firm-level internationalisation, regionalism and globalization, Palgrave MacMillan, Houndmills, Basingstoke, U.K., pp. 143-62.

Tenenhaus, M., Vinzi, V.E., Chatelin, Y.-M., and Lauro, C. (2005), "PLS path modeling", Computational Statistics \& Data Analysis, Vol. 48 No. 1, pp. 159-205.

Wang, E.T.G., Tai, J.C.F., and Wei, H.-L. (2006), "A virtual integration theory of improved supply-chain performance", Journal of Management Information Systems, Vol. 23 No. 2, pp. 41-64.

Weick, K.E. (1995), "What theory is not, theorizing is", Administrative Science Quarterly, Vol. 40 No. 3, pp. $385-90$

Williamson, O.E. (1975), Markets and hierarchies: Analysis and antitrust implications, Free Press, New York.

Wold, H. (1980), "Soft modelling: Intermediate between traditional model building and data analysis", Mathematical Statistics, Vol. 6, pp. 333-46.

Wu, F., Yeniyurt, S., Kim, D., and Cavusgil, S.T. (2006), "The impact of information technology on supply chain capabilities and firm performance: A resource-based view", Industrial Marketing Management, Vol. 35 No. 4, pp. 493-504.

Xia, Y. and Zhang, G.P. (2010), "The impact of the online channel on retailers' performances: An empirical evaluation", Decision Sciences, Vol. 41 No. 3, pp. 517-46.

Yamin, M. and Sinkovics, R.R. (2006), "Online internationalisation, psychic distance reduction and the virtuality trap", International Business Review, Vol. 15 No. 4, pp. 339-60. 


\section{Appendix - Tables and Figures}

\section{Table 1: Measurement scales}

Scale

Psychic Distance in terms of business practices being close $(C R=0.9833) * *($ Evans and Mavondo, 2002)

Basis for rewards and recognition e.g. procedure for promotion

Terms and conditions of employment at work *

Credit and financial arrangements in business *

Dealing with government bureaucracies *

Use of contracts and agreements in business *

Concept of fair dealings in business

Level of rules and regulations governing negotiation of property arrangements *

Psychic Distance in terms of business practices being distant $(C R=0.9606) * *$ (Evans and Mavondo, 2002)

Basis for rewards and recognition e.g. procedure for promotion

Terms and conditions of employment at work *

Level of bureaucracy i.e. adherence to budgets, schedules and procedures

Credit and financial arrangements in business *

Dealing with government bureaucracies *

Use of contracts and agreements in business *

Concept of fair dealings in business

Level of rules and regulations governing negotiation of property arrangements *

Psychic Distance in terms of national culture being close $(C R=0.9756) * *($ Evans and Mavondo, 2002)

Inequalities among people are minimized *

Employees are not afraid to express disagreement with their superiors *

Groups are very important

Tasks prevail over relationships in the workplace *

The dominant values in society are material success and progress rather than caring for others

There is stress placed upon equity, competition amongst colleagues and performance in the workplace *

Knowing influential people is usually more important than ability *

The workplace is a rather stressful environment $*$

Uncertainty is a normal feature of life

Companies' rules must not be broken *

There is resistance to change

Psychic Distance in terms of national culture being distant $(C R=0.9129) * *($ Evans and Mavondo, 2002)

Inequalities among people are minimized *

Employees are not afraid to express disagreement with their superiors *

Groups are very important

Tasks prevail over relationships in the workplace *

\begin{tabular}{|c|c|}
\hline Loading & t-value \\
\hline 0.9863 & 5.3535 \\
\hline 0.9532 & 61861 \\
\hline & \\
\hline & \\
\hline 0.9864 & 5.3548 \\
\hline & \\
\hline 0.9410 & 4.6136 \\
\hline 0.9740 & 4.5011 \\
\hline & \\
\hline & 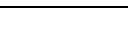 \\
\hline 0.9152 & 4.1718 \\
\hline & \\
\hline & \\
\hline 0.9616 & 9.228 \\
\hline 0.9615 & 101595 \\
\hline & \\
\hline & \\
\hline 0.9845 & 8.9595 \\
\hline 0.9045 & 7.6971 \\
\hline & \\
\hline & \\
\hline 0.7456 & 4.7152 \\
\hline & \\
\hline
\end{tabular}


The dominant values in society are material success and progress rather than caring for others

There is stress placed upon equity, competition amongst colleagues and performance in the workplace *

Knowing influential people is usually more important than ability *

The workplace is a rather stressful environment $*$

Uncertainty is a normal feature of life

Companies' rules must not be broken*

There is resistance to change

Export barrier reduction through the Internet $(C R=0.9999)$ (adapted from Bennett, 1997, unless stated otherwise)

The internet is an inexpensive way of communicating with customers (self-developed)

Using the Internet to market our products and services internationally lowers our overall marketing cost

The Internet helps us overcome problems associated with a lack of management time to devote to export matters *

The Internet helps us to reduce the financial costs associated with exporting

In the future we will devote more resources to our online business

The Internet makes it easier to overcome problems associated with a lack of knowledge about foreign markets

Thanks to the Internet, cultural differences between our market and foreign markets are less important

Customer acquisition through the Internet $(C R=0.8209)$

The Internet improves our ability to generate foreign sales leads (adapted from Bennett, 1997) *

The Internet helps us to reach more potential foreign customers (self-developed)

Because of the Internet we get unsolicited inquiries from foreign customers (self-developed)

Using the Internet to target foreign markets gives our company a competitive edge over rivals (adapted from Bennett, 1997)

Alternative to physical presence $(C R=0.8741)$

Completely withdrawing our physical presence from foreign markets is our key objective

Our Internet presence has given us a much better understanding of our industry in our target foreign markets *Self-developed

The online interaction with our foreign markets allows us to see things that we would have seen via physical interaction

Our company has gained the same customers as it would have via a physical presence in our foreign market

Market turbulencelenvironmental dynamism $(C R=0.8911)$

In our kind of business, customers' product preferences change quite a bit over time (adapted from Jaworski and Kohli, 1993)

Our customers tend to look for new products all the time (Jaworski and Kohli, 1993)

The price of the major product in our industry is very volatile (adapted from Noordewier, John, and Nevin, 1990) *

Sales forecasts in our business are quite inaccurate (adapted from Skarmeas, Katsikeas, and Schlegelmilch, 2002)

Market responsiveness $(C R=0.848)$

For one reason or another we tend to ignore changes in our customers' (product or service) needs (adapted from Jaworski and Kohli, 1993) (reversed)

Several individuals get together periodically to plan a response to changes taking place in our business environment (Jaworski and Kohli, 1993) *

The products we sell depend more on internal politics than real market needs (adapted from Jaworski and Kohli, 1993) (reversed)

Customers' complaints fall on deaf ears in our firm (adapted from Jaworski and Kohli, 1993) (reversed) *

Entrepreneurial disposition $(C R=0.799)$

When it comes to problem solving, we value creative solutions more than the solutions of conventional wisdom (Matsuno, Mentzer, and Özsomer, 2002) $*$

Top managers here encourage the development of innovative marketing strategies, knowing well that some will fail (Matsuno, Mentzer, and Özsomer, 2002)

We never stop searching for new ideas and opportunities

We test the outcome before we venture out (Manimala, 1999) *

\begin{tabular}{|c|c|}
\hline 0.6847 & 4.2371 \\
\hline & \\
\hline 0.9670 & 6.6227 \\
\hline 0.9769 & 7.3978 \\
\hline 0.9999 & 3.8402 \\
\hline 0.9999 & 10.6254 \\
\hline 0.9999 & 11.8637 \\
\hline 0.9999 & 7.7974 \\
\hline 0.9999 & 6.9461 \\
\hline 0.9999 & 7.6309 \\
\hline 0.8881 & 17.8577 \\
\hline 0.7287 & 6.1549 \\
\hline 0.7079 & 5.2191 \\
\hline 0.6897 & 13.5446 \\
\hline 0.8421 & 29.4723 \\
\hline 0.8310 & 20.0354 \\
\hline 0.8174 & 27.4611 \\
\hline 0.9458 & 11.8233 \\
\hline 0.8447 & 4.964 \\
\hline 0.9305 & 23.0154 \\
\hline 0.7807 & 7.8845 \\
\hline & \\
\hline & \\
\hline & \\
\hline 0.6552 & 12.2877 \\
\hline
\end{tabular}

Page $\mathbf{2 5}$ of $\mathbf{3 1}$ 
We value the orderly and risk-reducing management process much more highly than leadership initiatives for change (Manimala, 1999) *

Top managers in our firm like to "play it safe" (Matsuno, Mentzer, and Özsomer, 2002) (reversed) *

Top managers around here like to implement plans only if they are very certain that they will work (Matsuno, Mentzer, and Özsomer, 2002) *

Employees of this firm tend to talk more about opportunities rather than problems (Matsuno, Mentzer, and Özsomer, 2002)

This company is always experimenting with new ways of doing things (self-developed)

Online sales channel (CR $=0.9999)$ (Wu et al., 2006)

Our company website is used to order and purchase our goods or services internationally (self-developed)

Our company uses the most advanced IT systems to interact with our foreign customers (Wu et al., 2006) *

The IT we use for the management of our international operations is always state-of-the-art technology (Wu et al., 2006) *

Relative to our competitors, the IT we use for export management is more advanced (Wu et al., 2006) *

In our industry, our company is always first to use new IT for the management of our international operations (adapted from Wu et al., 2006) *

In our industry, our company is regarded as an IT leader in export management (Wu et al., 2006) *

Export performance $(C R=0.9294)$ (Katsikeas, Leonidou, and Morgan, 2000)

How satisfied are you with the results of your exporting activities?

Export sales growth

Export sales volume

Contribution of exporting to profits

New products exported

Overall export performance

* items dropped in the final analysis

** 7-point Likert Scale (very dissimilar $=1$; very similar $=7$ ) otherwise, 7-point Likert Scale $($ strongly disagree $=1$; strongly agree $=7$ ) 
Table 2: Company characteristics organized by industry and born-globalness of firms

\begin{tabular}{|l|l|l|l|l|l|l|}
\hline Industry & $\begin{array}{l}\text { Born- } \\
\text { globalness }\end{array}$ & $\begin{array}{l}\text { Internet } \\
\text { experience (in } \\
\text { years) }\end{array}$ & $\begin{array}{l}\text { Firm age (in } \\
\text { years) }\end{array}$ & $\begin{array}{l}\text { Export } \\
\text { experience (in } \\
\text { years) }\end{array}$ & $\begin{array}{l}\text { Export ratio } \\
(\%)\end{array}$ & $\begin{array}{l}\text { Revenue (in } \\
\text { million } £)\end{array}$ \\
\hline \multirow{2}{*}{ Low-tech } & Non-BG & 11 & Mean & Mean & Mean & Mean \\
\cline { 2 - 7 } & BG & 9 & 47 & 28 & $32.99 \%$ & 10.70 \\
\hline High-tech & Non-BG & 10 & 29 & 24 & $48.80 \%$ & 11.85 \\
\cline { 2 - 7 } & BG & 11 & 60 & 29 & $32.22 \%$ & 16.66 \\
\hline
\end{tabular}

Table 3: Company characteristics

\begin{tabular}{|l|l|l|l|}
\hline \multirow{2}{*}{ Dimension } & $\begin{array}{l}\text { Number } \\
\text { of firms }\end{array}$ & $\begin{array}{l}\text { Percentage of } \\
\text { firms }\end{array}$ \\
\hline \multirow{2}{*}{$\begin{array}{l}\text { Born- } \\
\text { globalness }\end{array}$} & BG & 58 & $50.43 \%$ \\
\cline { 2 - 4 } & non-BG & 57 & $49.57 \%$ \\
\hline Industry & Low-tech & 54 & $46.96 \%$ \\
\cline { 2 - 4 } & High-tech & 61 & $53.04 \%$ \\
\hline Employees & $1-9$ & 2 & $1.74 \%$ \\
\cline { 2 - 4 } & $10-49$ & 27 & $23.48 \%$ \\
\cline { 2 - 4 } & $50-149$ & 63 & $54.78 \%$ \\
\cline { 2 - 4 } & $150-250$ & 22 & $19.13 \%$ \\
\hline Export ratio & $<10 \mathrm{~m}$ & 13 & $11.30 \%$ \\
\cline { 2 - 4 } & $10-24.99 \mathrm{~m}$ & 18 & $15.65 \%$ \\
\cline { 2 - 4 } & $25-49.99 \mathrm{~m}$ & 33 & $28.70 \%$ \\
\cline { 2 - 4 } & $50-74.99 \mathrm{~m}$ & 30 & $26.09 \%$ \\
\cline { 2 - 4 } & $>75 \mathrm{~m}$ & 19 & $16.52 \%$ \\
\hline \multirow{5}{*}{ Revenue } & $1.00:<1 \mathrm{~m}$ & 2 & $1.74 \%$ \\
\cline { 2 - 4 } & $2.00: 1 \mathrm{~m}-4.99 \mathrm{~m}$ & 21 & $18.26 \%$ \\
\cline { 2 - 4 } & $3.00: 5 \mathrm{~m}-9.99 \mathrm{~m}$ & 31 & $26.96 \%$ \\
\cline { 2 - 4 } & $4.00: 10 \mathrm{~m}-24.99 \mathrm{~m}$ & 36 & $31.30 \%$ \\
\cline { 2 - 4 } & $5.00: 25 \mathrm{~m}-50 \mathrm{~m}$ & 19 & $16.52 \%$ \\
\hline
\end{tabular}


Table 4: Overall model evaluation

\begin{tabular}{|l|l|l|l|l|l|}
\hline & AVE & $\begin{array}{l}\text { Highest squared } \\
\text { correlation }\end{array}$ & $\begin{array}{l}\text { Composite } \\
\text { Reliability }\end{array}$ & $\begin{array}{l}\text { R } \\
\text { Square }\end{array}$ & $\begin{array}{l}\text { Cronbach } \\
\text { Alpha }\end{array}$ \\
\hline Business practices close & 0.9514 & 0.5507 & 0.9833 & 0 & 0.9744 \\
\hline Business practices & 0.8906 & 0.5809 & 0.9606 & 0 & 0.9386 \\
\hline Entrepreneurial disposition & 0.572 & 0.0567 & 0.799 & 0 & 0.6436 \\
\hline National culture close & 0.9091 & 0.6722 & 0.9756 & 0 & 0.9713 \\
\hline National culture distant & 0.7285 & 0.6722 & 0.9129 & 0 & 0.9387 \\
\hline Alternative to a physical presence & 0.6359 & 0.0503 & 0.8741 & 0.1284 & 0.8061 \\
\hline Internet as export barrier reduction & 0.9999 & 0.0503 & 0.9999 & 0.6602 & 0.9997 \\
\hline Customer acquisition potential & 0.6069 & 0.0513 & 0.8209 & 0 & 0.6821 \\
\hline Environmental turbulence & 0.804 & 0.0210 & 0.8911 & 0 & 0.7693 \\
\hline Market responsiveness & 0.7377 & 0.0503 & 0.848 & 0 & 0.6644 \\
\hline Internet as sales channel & 0.9998 & 0.4436 & 0.9999 & 0.0567 & 0.9998 \\
\hline Export performance & 0.729 & 0.4436 & 0.9294 & 0.4664 & 0.9586 \\
\hline
\end{tabular}


Table 5: Control variables

\begin{tabular}{|c|c|c|c|c|c|c|c|c|c|}
\hline & $\begin{array}{l}\text { Full } \\
\text { Sample }\end{array}$ & \multicolumn{8}{|c|}{ Control Variables } \\
\hline & & \multicolumn{2}{|c|}{ Born-globalness } & \multicolumn{2}{|l|}{ Industry } & \multicolumn{2}{|c|}{ Export experience } & \multicolumn{2}{|c|}{ Internet experience } \\
\hline & & BG & non-BG & low-tech & $\begin{array}{l}\text { high- } \\
\text { tech }\end{array}$ & $<50 \%$ & $>50 \%$ & $<10 \mathrm{yrs}$ & $>10 \mathrm{yrs}$ \\
\hline Export performance & $\mathrm{N}=115$ & $\mathrm{~N}=58$ & $\mathrm{~N}=57$ & $\mathrm{~N}=54$ & $\mathrm{~N}=61$ & $\mathrm{~N}=65$ & $\mathrm{~N}=50$ & $\mathrm{~N}=46$ & $\mathrm{~N}=69$ \\
\hline & $\begin{array}{l}\mathrm{R}^{2}= \\
0.4664\end{array}$ & $\begin{array}{l}\mathrm{R}^{2}= \\
0.1041\end{array}$ & $\begin{array}{l}\mathrm{R}^{2}= \\
0.4477\end{array}$ & $\begin{array}{l}\mathrm{R}^{2}= \\
0.4440\end{array}$ & $\begin{array}{l}\mathrm{R}^{2}= \\
0.0241\end{array}$ & $\begin{array}{l}\mathrm{R}^{2}= \\
0.9918\end{array}$ & $\begin{array}{l}\mathrm{R}^{2}= \\
0.1867\end{array}$ & $\begin{array}{l}\mathrm{R}^{2}= \\
0.9859\end{array}$ & $\begin{array}{l}\mathrm{R}^{2}= \\
0.0732\end{array}$ \\
\hline $\begin{array}{l}\text { Alternative to phys. } \\
\text { presence }\end{array}$ & $0.1512^{\mathrm{a}}$ & $-0.2925 *$ & $0.1972^{\mathrm{a}}$ & $0.2116 *$ & 0.0685 & -0.0105 & $0.3555 *$ & 0.0056 & $0.2247^{\mathrm{a}}$ \\
\hline Sales channel & $0.6762 *$ & 0.1037 & $0.6555 *$ & 0.6533* & 0.1331 & $0.9947 *$ & 0.2355* & $0.9937 *$ & $0.1292^{\mathrm{a}}$ \\
\hline Sales channel & $\mathrm{N}=115$ & $\mathrm{~N}=58$ & $\mathrm{~N}=57$ & $\mathrm{~N}=54$ & $\mathrm{~N}=61$ & $\mathrm{~N}=65$ & $\mathrm{~N}=50$ & $\mathrm{~N}=46$ & $\mathrm{~N}=69$ \\
\hline & $\begin{array}{l}R^{2}= \\
0.0567\end{array}$ & $\begin{array}{l}\mathrm{R}^{2}= \\
0.2556\end{array}$ & $\begin{array}{l}\mathrm{R}^{2}= \\
0.1031 \\
\end{array}$ & $\begin{array}{l}\mathrm{R}^{2}= \\
0.1407\end{array}$ & $\begin{array}{l}\mathrm{R}^{2}= \\
0.0992\end{array}$ & $\begin{array}{l}\mathrm{R}^{2}= \\
0.1129\end{array}$ & $\begin{array}{l}R^{2}= \\
0.1646\end{array}$ & $\begin{array}{l}\mathrm{R}^{2}= \\
0.1952\end{array}$ & $\begin{array}{l}\mathrm{R}^{2}= \\
0.1201\end{array}$ \\
\hline $\begin{array}{l}\text { Entrepreneurial } \\
\text { disposition }\end{array}$ & $0.2381 *$ & $0.5056 *$ & 0.3210* & $0.3752 *$ & $0.3149 *$ & $0.3360 *$ & $0.4057 *$ & $0.4418 *$ & $0.3465 *$ \\
\hline $\begin{array}{l}\text { Alternative to phys. } \\
\text { presence }\end{array}$ & $\mathrm{N}=115$ & $\mathrm{~N}=58$ & $\mathrm{~N}=57$ & $\mathrm{~N}=54$ & $\mathrm{~N}=61$ & $\mathrm{~N}=65$ & $\mathrm{~N}=50$ & $\mathrm{~N}=46$ & $\mathrm{~N}=69$ \\
\hline & $\begin{array}{l}\mathrm{R}^{2}= \\
0.1284\end{array}$ & $\begin{array}{l}\mathrm{R}^{2}= \\
0.3167\end{array}$ & $\begin{array}{l}\mathrm{R}^{2}= \\
0.1416\end{array}$ & $\begin{array}{l}\mathrm{R}^{2}= \\
0.2523\end{array}$ & $\begin{array}{l}\mathrm{R}^{2}= \\
0.2025\end{array}$ & $\begin{array}{l}\mathrm{R}^{2}= \\
0.2398\end{array}$ & $\begin{array}{l}\mathrm{R}^{2}= \\
0.3238\end{array}$ & $\begin{array}{l}\mathrm{R}^{2}= \\
0.3199\end{array}$ & $\begin{array}{l}\mathrm{R}^{2}= \\
0.1192\end{array}$ \\
\hline Cust acquisition & $0.2204 *$ & 0.1435* & $0.1836 *$ & 0.0723 & 0.4118* & 0.0668 & 0.1299* & 0.0653 & 0.1985* \\
\hline $\begin{array}{l}\text { Environmental } \\
\text { turbulence }\end{array}$ & $-0.1695^{*}$ & $-0.1246^{\mathrm{a}}$ & $-0.1627 *$ & $-0.3399 *$ & -0.0166 & $0.1162 *$ & -0.0466 & $-0.1848^{a}$ & $-0.1948 *$ \\
\hline $\begin{array}{l}\text { Market } \\
\text { responsiveness }\end{array}$ & $0.2474 *$ & $0.3546 *$ & $0.2719 *$ & $0.2615^{*}$ & $0.2509 *$ & $-0.2301 *$ & 0.0949 & 0.3811* & $0.2017 *$ \\
\hline Barrier reduction & 0.0622 & $0.4482 *$ & 0.0809 & $0.3043^{*}$ & $0.0931^{\mathrm{a}}$ & 0.3896 & 0.5084* & $0.3042 *$ & 0.0690 \\
\hline Barrier reduction & $\mathrm{N}=115$ & $\mathrm{~N}=58$ & $\mathrm{~N}=57$ & $\mathrm{~N}=54$ & $\mathrm{~N}=61$ & $\mathrm{~N}=65$ & $\mathrm{~N}=50$ & $\mathrm{~N}=46$ & $\mathrm{~N}=69$ \\
\hline & $\begin{array}{l}\mathrm{R}^{2}= \\
0.4926\end{array}$ & $\begin{array}{l}\mathrm{R}^{2}= \\
0.0536\end{array}$ & $\begin{array}{l}\mathrm{R}^{2}= \\
0.6297\end{array}$ & $\begin{array}{l}\mathrm{R}^{2}= \\
0.0444\end{array}$ & $\begin{array}{l}\mathrm{R}^{2}= \\
0.9998\end{array}$ & $\begin{array}{l}\mathrm{R}^{2}= \\
0.9607\end{array}$ & $\begin{array}{l}\mathrm{R}^{2}= \\
0.0369\end{array}$ & $\begin{array}{l}\mathrm{R}^{2}= \\
0.0986\end{array}$ & $\begin{array}{l}\mathrm{R}^{2}= \\
0.5136\end{array}$ \\
\hline BP close & $-0.9762 *$ & $0.3012^{\mathrm{a}}$ & $-0.9546 *$ & 0.1775 & -0.9746 & $-0.4262^{\mathrm{a}}$ & -0.2366 & 0.3446 & $-0.8974 *$ \\
\hline BP distant & $0.7346^{*}$ & 0.1133 & $0.6573^{\mathrm{a}}$ & -0.073 & -0.0079 & 0.2281 & -0.1966 & -0.4917 & $0.6982 *$ \\
\hline NC close & 0.7478* & 0.1439 & 0.9478* & 0.1957 & 0.9682 & $0.6110 *$ & 0.5074 & -0.6133 & $0.8952 *$ \\
\hline $\mathrm{NC}$ distant & -0.1880 & 0.1014 & -0.1965 & -0.0929 & 0.0035 & 0.7528* & -0.3223 & 0.5156 & $-0.3564^{\mathrm{a}}$ \\
\hline
\end{tabular}

*... significant at the 0.05 level.

a... significant at the 0.10 level 
Figure 1: Conceptual Framework

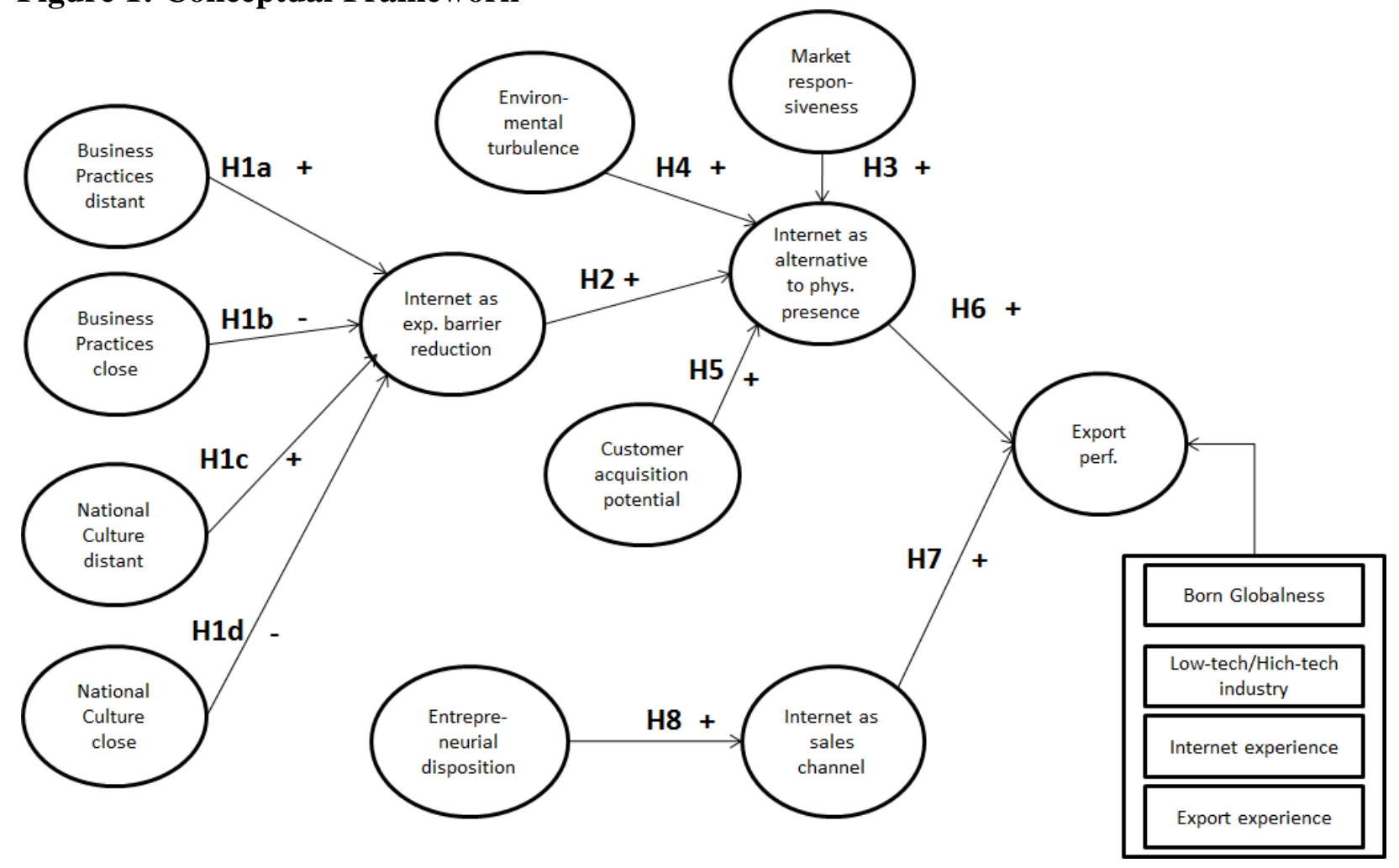


Figure 2 Results of the PLS structural model for $N=115$

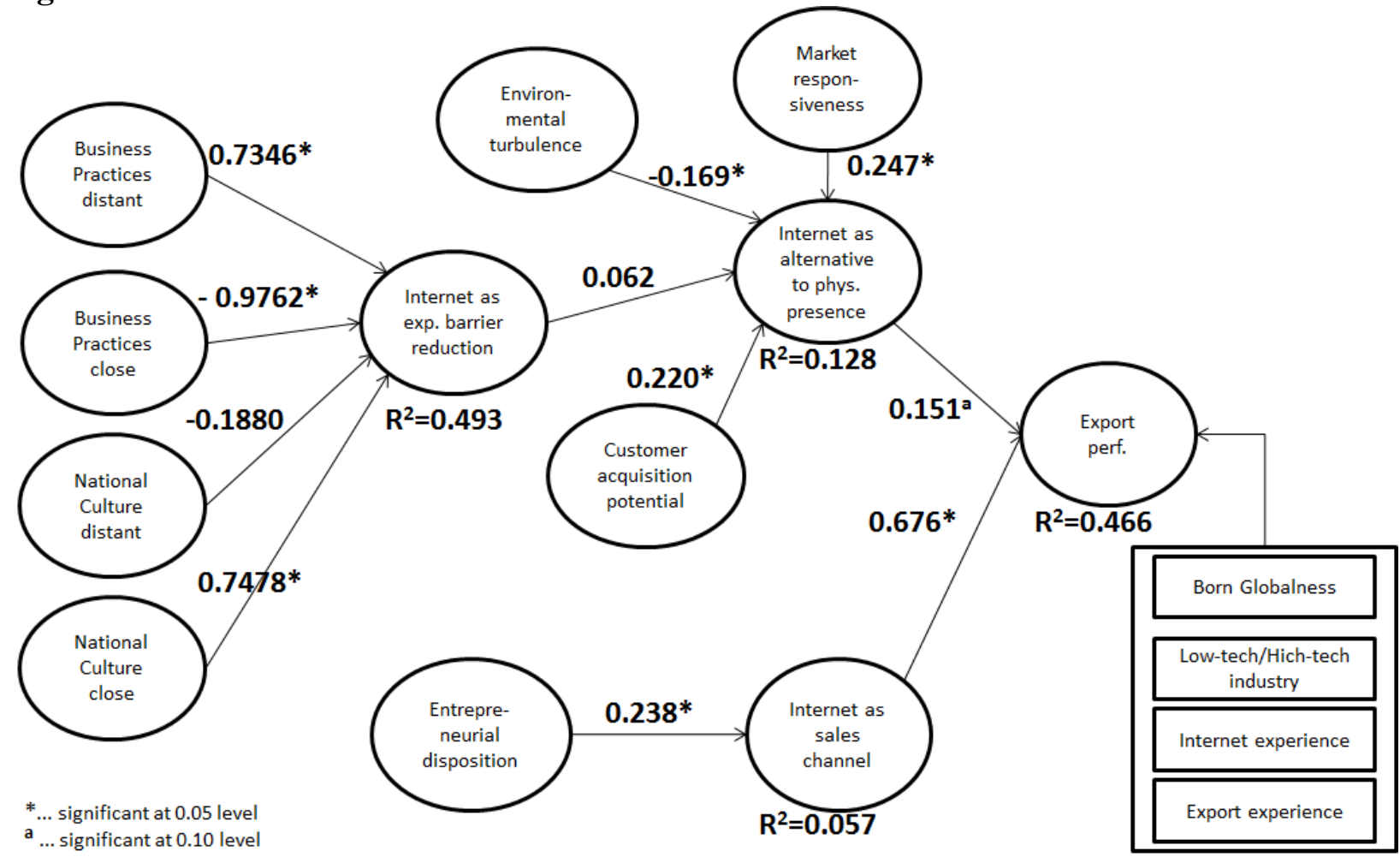

